\title{
Phytochemical screening and oral acute toxicity study of aqueous leaf extract of Crinum giganteum (gadalli) in Wistar rats
}

\author{
F. B. Elizabeth ${ }^{1,2 *}$, E. N. Obikili ${ }^{1}$, A. E. Esom ${ }^{1}$, G. E. Anyanwu ${ }^{1}$ \\ 'Department of Anatomy, University of Nigeria, UNEC, Enugu, Nigeria, ²Department of Anatomy, Ebonyi State University, Abakaliki, \\ Ebonyi State, Nigeria
}

Received: 16.03 .2016

Accepted: 27.03.2016

Published: 10-05-2016

*Address for correspondence:

F. B. Elizabeth,

Department of Anatomy,

University of Nigeria,

UNEC, Enugu, Nigeria.

Tel.: +2348084113179,

E-mail: finbello@yahoo.com

\begin{abstract}
Different parts of plants possess variable phytochemical compounds and median lethal dose $\left(\mathrm{LD}_{50}\right)$. Crinum giganteum (gadalli) is one of the plants most commonly consumed in parts of Africa for its various medicinal values. Despite this popularity, the phytochemical screening and the toxicity of the leaf extracts were yet to be evaluated. This study was designed to identify the bioactive agents and estimate the $\mathrm{LD}_{50}$ for the aqueous leaf extract of gadalli. Phytochemical screening was done using standard methods. Each bioactive agent and the $\mathrm{LD}_{50}$ were estimated by the arithmetic methods of Karber. Phytochemical analysis revealed high presence of alkaloids, saponins, and slight presence of glycosides, whereas the oral $\mathrm{LD}_{50}$ was found to be $200 \mathrm{mg} / \mathrm{kg}$. The major active ingredients of aqueous leaf extract of gadalli are alkaloids and saponins. It is observed to be unsafe at $200 \mathrm{mg} / \mathrm{kg}$ and above.
\end{abstract}

KEY WORDS: Alkaloids, Crinum giganteum, glycosides, median lethal dose, phytochemicals, saponins

\section{INTRODUCTION}

Phytochemicals or bioactive agents describe secondary metabolic compounds found in plants (Engwa et al., 2011; Sasidharan et al., 2011; Yadav and Munin, 2011; Kennedy and Wightman, 2012) and are synonymously called phytonutrients, phytofood, and nutraceuticals (Prashant et al., 2011; Shorbha, 2012). They evolve as chemicals produced by plants against predators and infections, such as bacteria, insects, and fungi (Shorbha, 2012; Engwa et al., 2013). These agents can be derived from any plant parts such as the barks, leaves, flowers, roots, fruits, stems, seeds, and bulbs (Yadav and Munin, 2011). Generally, different plants and/or parts have different composition and load of phytochemical agents and the predictions depend on the type of solvents used in the extraction (Shorbha, 2012; Lalnundanga and Lalrinkima, 2012). Several studies have consistently reported the following secondary bioactive substances in medicinal plant extracts: Alkaloids, steroids, phenols, tannins, saponins, flavonoids, and glycosides (Sasidharan et al., 2011; Yadav and Munin, 2011).
While the phytochemicals dictate the biological activity of the extract, the median lethal dose $\left(\mathrm{LD}_{50}\right)$ indicates the degree of safety of a particular plant extract. Studies have shown that extracts of a plant part have different $\mathrm{LD}_{50}$ across the different routes of administration and animal species (Rafaat et al., 2012; 2013). Crinum giganteum (gadalli) is a perennial herb found in parts of Cameroun, Niger, and Nigeria. The plant is also known by other names in different ethnic groups across Africa (Keay 1989). It is called Wadalo by the Bororo's of Cameroun and Daffun of Adamawa in North-East Nigeria. The Bororo's of the Niger Republic calls it Lubo and among the Hausa's in northern Nigeria, it is known as Albacce Buru or Albacce Dawaddi (Keay, 1989). The bulb extract of $C$. giganteum has been found to possess alkaloids and tannins with intraperitoneal $\mathrm{LD}_{50}$ of $627 \pm 5.8 \mathrm{mg} / \mathrm{kg}$ and $520 \pm 10.2 \mathrm{mg} / \mathrm{kg}$ in mice and rats, respectively and also oral $\mathrm{LD}_{50}$ of $1486 \pm 18.9 \mathrm{mg} / \mathrm{kg}$ and $1023 \pm 4.3 \mathrm{mg} / \mathrm{kg}$ in mice and rats, respectively (Kapu et al., 2001). There is a paucity of information on the phytochemical agents and $\mathrm{LD}_{50}$ of the aqueous leaf extract of $C$. giganteum despite the increasing rate of the consumption of the leaf and other parts of this plant as a 
result of its various medicinal values. Hence, this study was designed to evaluate the bioactive agents and estimate the oral $\mathrm{LD}_{50}$ for the aqueous leaf extract.

\section{MATERIALS AND METHODS}

\section{Collection and Identification of Plant Materials}

The plant material was procured from an open market in Adamawa State, North-East of Nigeria. Identification was done by a taxonomist; Prof. Mrs. M. O Nwosu of the Department of Plant Science and Biotechnology, University of Nigeria, Nsukka. Herbarium sheet was prepared and a voucher specimen (UNH/13/401) was deposited at the herbarium of same department.

\section{Phytochemical Screening}

The gadalli leaves were washed with distilled water and air-dried under shade for 7 days. Thereafter, the leaves were pulverized into fine powder by pestle and mortar. Hundred grams of the dried leaf powder were placed in a beaker containing $500 \mathrm{ml}$ of distilled water and heated using a hot plate with continuous stirring at $30-40^{\circ} \mathrm{C}$ for $20 \mathrm{~min}$. The mixture was then allowed to cool and filtration was done using a mesh cloth. The extract was then evaluated for the presence of alkaloids, flavonoids, glycosides, phenols, saponins, steroids, and tannins by using the following procedure.

\section{Test for alkaloids}

Exactly one milliliter $(1 \mathrm{ml})$ of $1 \%$ hydrochloric acid was added to $3 \mathrm{ml}$ of the extract in a test tube. The mixture was heated for $20 \mathrm{~min}$ in a water bath, allowed to cool, and then filtered. Two drops of Wagner's reagent were added to $1 \mathrm{ml}$ of the filtrate. A reddish brown precipitate observed indicated the presence of alkaloids.

\section{Test for flavonoids}

About $1 \mathrm{ml}$ of $10 \%$ sodium hydroxide $(\mathrm{NaOH})$ was added to $3 \mathrm{ml}$ of the extract. Absence of yellow coloration indicated the absence of flavonoids.

\section{Test for glycosides}

About $10 \mathrm{ml}$ of $50 \%$ tetraoxosulfate (VI) acid $\left(\mathrm{H}_{2} \mathrm{SO}_{4}\right)$ was added to $1 \mathrm{ml}$ of the extract in a test tube. The mixture was heated in boiling water for $15 \mathrm{~min}$. About $10 \mathrm{ml}$ of Fehling's solution was added and the mixture was boiled. A brick-red precipitate was observed in the test mixture, which indicated the presences of glycosides.

\section{Test for phenols}

A small portion $(1 \mathrm{ml})$ of the extract was added to $1 \mathrm{ml}$ of water and few drops of $5 \% \mathrm{NAOH}$ were added.
Absence of orange coloration is indicative of the absence of phenol.

\section{Test for saponins}

The presences of saponins were detected using frothing test. In the test, $2 \mathrm{ml}$ of the extract was vigorously shaken for $2 \mathrm{~min}$. Frothing observed in the extract indicated the presences of saponins.

\section{Test for steroids}

Presence of steroids was investigated using Salkowski test in which 5 drops of concentrated $\left(\mathrm{H}_{2} \mathrm{SO}_{4}\right)$ were added to $1 \mathrm{ml}$ of the extracts. No red coloration was observed in the mixture, indicating the absence of steroids.

\section{Test for tannins}

Exactly $2 \mathrm{ml}$ of the extract was boiled gently for $2 \mathrm{~min}$ and allowed to cool. Three drops of ferric chloride solution were added. Absence of green coloration is indicative of the absence of tannins.

\section{Procurement and Care of Animals}

About 20 adult Wistar rats of both sexes of average weights of $200 \mathrm{~g}$ were purchased from the animal house of the College of Medicine, University of Nigeria, Enugu Campus, and housed in the Animal facility of the same institution. The animals were housed in netted iron cages in groups of four, fed with grower's mash and provided water ad libitum. The rats were maintained under standard laboratory conditions (temperature $24^{\circ} \mathrm{C} \pm 2{ }^{\circ} \mathrm{C}$, with relative humidity of $60-70 \%$, and a $12 \mathrm{~h}$ light-dark cycle). They were allowed to acclimatize for 2 weeks before the experiment. This study was approved by the University of Nigeria Teaching Hospital, Health Research Ethics Committee, with certificate number NKREC/05/01/2008B-FWA000024581RB00002323.

\section{Oral Toxicity Study}

The animals were divided into five groups (A-E) of four animals each. Animals in Groups B-E served as the toxicity test groups whereas that in Group A were taken as the control group. Animals in Groups B, C, D, and E were orally administered increasing doses of 200, 400, 800, and $1600 \mathrm{mg} / \mathrm{kg}$ of the aqueous extract of $C$. giganteum per body weight, respectively. The control group received $0.1 \mathrm{ml}$ of distilled water orally. The animals were observed for signs of acute toxicity such as behavioral changes and death over $48 \mathrm{~h}$ and $\mathrm{LD}_{50}$ was estimated using the arithmetic method of Karber as modified by Aliu and Nwude (1982). 


\section{RESULTS}

\section{Phytochemical Analysis}

From the results of the various phytochemical screening, high presences of alkaloids and saponins, and slight presence of glycosides were noted. Tannins, phenols, flavonoids, and steroids were found to be absent in the extracts studied (Table 1).

\section{Oral Acute Toxicity Study}

None of the animals in Groups B and C showed any clinical or behavioral changes throughout the observational period. However, depression, weakness, and loss of appetite in the first $3 \mathrm{~h}$ were observed in Groups D and E animals treated with the higher doses of the extract. Attempt at recovery from toxicity was observed on the $8^{\text {th }} \mathrm{h}$ in two animals in Group D and one in Group E whereas other showed clonic convulsion, anesthesia, tonic extension, salivation, and eventually died within the 48 $\mathrm{h}$ after the administration. The $\mathrm{LD}_{50}$ of the $C$. giganteum extract was estimated as described by Aliu and Nwude (1982) (Table 2) and calculated to be $200 \mathrm{mg} / \mathrm{kg}$ body weight.

The $\mathrm{LD}_{50}$ was calculated using the formula:

$\mathrm{LD}_{50}=\mathrm{LD}_{\mathrm{y}}-\sum(\mathrm{Ddx} \mathrm{md}) \mathrm{N}$

Where,

$\mathrm{LD}_{\mathrm{y}}=$ Highest dose

Table 1: Result of phytochemical screening of the aqueous leaf extract

\begin{tabular}{lc}
\hline Parameter & Remark \\
\hline Alkaloids & +++ \\
Saponins & +++ \\
Flavonoids & --- \\
Phenols & --- \\
Steroids & --- \\
Tannins & --- \\
Glycosides & +-- \\
\hline
\end{tabular}

Highly present $(+++)$, Slightly present $(+--)$, Absent (---)

Table 2: Oral acute toxicity $\left(\mathrm{LD}_{50}\right)$ of $C$. giganteum in rats

\begin{tabular}{lccccc}
\hline Dose $(\mathrm{mg} / \mathrm{kg})$ & $\begin{array}{c}\text { Number } \\
\text { of rats }\end{array}$ & $\begin{array}{c}\text { Death } \\
\text { difference } \\
\text { (a) }\end{array}$ & $\begin{array}{c}\text { Mean } \\
\text { death } \\
\text { (b) }\end{array}$ & $\begin{array}{c}\text { Probit=dose } \\
\text { diff/mean death } \\
\text { (a and b) }\end{array}$ \\
\hline Control (1 ml, & 4 & 0 & 0 & 0 & 0 \\
$0.9 \%$ saline) & & & & & \\
200 & 4 & 0 & 0 & 0 & 0 \\
400 & 4 & 0 & 200 & 0 & 0 \\
800 & 4 & 2 & 400 & 1 & 400 \\
1600 & 4 & 3 & 800 & 2.5 & 2000 \\
& & & & & 2400 \\
\hline
\end{tabular}

$\mathrm{LD}_{50}$ : Median lethal dose, C. giganteum: Crinum giganteum
$\mathrm{N}=$ Number of animals per group

Dd $=$ Dose difference

Md $=$ Mean dead

$\mathrm{LD}_{50}=\frac{2400}{400}=600$

$800-600=200 \mathrm{mg} / \mathrm{kg}$

\section{DISCUSSIONS}

The presence of alkaloids, saponins, and glycosides indicate that the plant has some medicinal properties which can be exploited for therapeutic purposes (Jodi et al., 2008). Phytochemical analyses of the aqueous bulb extract of C. giganteum had revealed the presences of the other bioactive agent such as tannins (Amos et al., 2003), which was not found in the aqueous leaf extract in the present study. This confirmed that different parts of a plant could possess different composition or load of phytochemical agents (Shorbha, 2012). The presence of alkaloids agrees with the fact that the Crinum species are generally well known rich sources of alkaloids (Rafaat et al., 2012; Rafaat et al., 2013).

The estimated oral $\mathrm{LD}_{50}$ for the aqueous leaf extract of C. giganteum (gadalli) in this study was $200 \mathrm{mg} / \mathrm{kg}$. This implies that doses below the $\mathrm{LD}_{50}$ can be considered safe for experimental study using this extract. Precisely, onetenth of the $\mathrm{LD}_{50}$ has been advocated for in the choice of safe dose for use in various studies or clinical trials (Jodi et al., 2008). The oral $\mathrm{LD}_{50}$ of $200 \mathrm{mg} / \mathrm{kg}$ of this extract was different from reports of Amos et al. (2003) that found intraperitoneal and oral $\mathrm{LD}_{50}$ of $627 \mathrm{mg} / \mathrm{kg}$ and $1468 \mathrm{mg} / \mathrm{kg}$, respectively, of the aqueous bulb extract of C. giganteum in mice.

The part of a plant, route of exposure of drug and the specie of animal used account for the various differences in the $\mathrm{LD}_{50}$ values of an extract. The variations observed in the $\mathrm{LD}_{50}$ values across different routes of exposure have been attributed to the plasma concentrations and bioavailability of the extracts. Particularly, for an extract, this pharmacological properties might be influenced by the nature or properties of the active principles (phytochemicals) present in the extract.

\section{CONCLUSION}

The aqueous leaf extract of $C$. giganteum contain alkaloids, glycosides, and saponins whereas the $\mathrm{LD}_{50}$ was found to be $200 \mathrm{mg} / \mathrm{kg}$. However, it is considered safe at doses lower than $200 \mathrm{mg} / \mathrm{kg}$. 


\section{REFERENCES}

Aliu AY, Nwude N. Veterinary Pharmacology and Toxicology Experiments. $1^{\text {st }}$ ed. Nigeria: Baraka Press Zaria; 1982. p. 104-9.

Amos S, Binda L, Akah P, Wambebe C, Gamaniel K. Central inhibitory activity of the aqueous extract of Crinum giganteum. Fitoterapia 2003;74:23-8.

Engwa AG, Nnamdi P, Nnadi JC, OfforT, Eze BC. Comparative qualitative analysis of the phytochemical load of water, methanol, ethyl acetate and hexane extracts of six selected medicinal plants. Int J Pharmacogn Phytochem Res 2011;5:164-7.

Jodi SM, Adamu T, Abubakar U, Abubakar MG, Adamu S, Ukato VE. Phytochemical and acute toxicity studies on the ethanol roots extract of Gardenia sokotensis. Sokoto J Vet Sci 2008;7:68-70.

Kapu SD, Ngwai YB, Kayode O, Akah PA, Wambebe C, Gamaniel K. Anti-inflammatory, analgesic and antilymphocytic activities of the aqueous extract of Crinum giganteum. J Ethnopharmacol 2001;78:7-13.

Keay RW. Trees of Nigeria. UK: Oxford University Press; 1989. p. 1-6.

Kennedy DO,Wightman EL. Herbal extracts and phytochemicals:
Plant secondary metabolites and the enhancement of human brain function. Adv Nutr 2011;2:32-50.

Lalnundanga NL, Lalrinkima R. Phytochemical analysis of the methanol extract of root bark of Hiptage benghalensis (L.) Kurz. Sci Vis 2012;12:8-10.

Prashant T, Bimlesh K, Mandeep K, Gurpreet K, Harleen K. Phytochemical screening and extraction: A review. Int Pharm Sci 2011;1:98-106.

Rafaat J, Mahumood SK, Mahmood AR, Ahmed A. Al. Crinum; An endless source of bioactive principles: A review. Part 1: Crinum alkaloids: Lycorine type alkaloid. IJPSR 2012;3:1883-90.

Rafaat J, Mahumood SK, Mahmood AR, Ahmed A. Al. Crinum; An endless source of bioactive principles: A review. PartV; Biological profile. JPSR 2013;4:1239-52.

Sasidharan S, Chen Y, Saravanan D, Sundram KL, Yoga LL. Extraction, isolation and characterization of bioactive compounds from plants' extracts. Afr JTradit Complement Altern Med 2011;8:1-10.

Shorbha B. Antibacterial activity phytochemical analysis of water extract of Syzygium cumini and analytical study HPLC. Asian J Exp Boil Sci 2012;3:320-524.

Yadav R, Munin A. Phytochemical analysis of some medicinal plants. J Phytol 2011;3:10-4. 